\title{
Fighting Corruption
}

\begin{abstract}
This chapter describes the measures taken in Georgia after the 2004 to fight corruption, eradicate the shadow economy, and promote economic growth. Examples of such measures include better pay for public officials, performance rewards, deregulation, simplification of regulation, and investments in checks and balances. Based on his experience leading successful anti-corruption reforms, the author challenges the widespread belief that corruption is innate in societies and provides both concrete examples of creative corruption-prevention approaches, such as mystery shopping, and evidence of the impact of his reforms in Georgia, such as the country's performance in Transparency International's Corruption Perception Index and the Global Corruption Barometer.
\end{abstract}

Keywords Urgency · Administration - Meritocracy · Bureaucrats · Laffer curve $\cdot$ Procurement $\cdot$ Electronic $\cdot$ Transparent $\cdot$ Tender $\cdot$ Auction

When the new government was approved in the winter of 2004, Georgia was falling apart economically. GDP per capita was at the level of thirdworld countries like Togo or Malawi. Almost half the population was either unemployed or earning only a few dollars a month. But more importantly, the country was running dramatically low on trust. If we wanted to save Georgia, we would have to make the government and its 
agents accountable for their actions. Public officials would have to start playing by the rules, and those who didn't would have to be brought to justice. We wanted Georgians to trust their leaders, and foreign investors to trust the Georgian economy as a whole. Fighting corruption was the key to both of these goals.

\subsection{DON'T Waste a CRISIS}

I refuse to believe that corruption is innate in any person or society. Corruption results from poor choices, and it is the main obstacle for any country to grow. Some countries may grow despite high levels of corruption, usually fueled by natural resources. But such growth is not sustainable, and it doesn't create a middle class capable of serving as the backbone of a stable society, unless substantial reforms are conducted in time.

Until 2004, Georgia had been in the hands of leaders who accepted corruption as a lesser evil. But in 2003, the Rose Revolution changed the game. The crisis engendered an unprecedented willingness to change, as well as a sense of urgency shared by everyone. The vast majority of the population was fed up with being cheated out of their own country by the ruling elite and its accomplices. An approval rate of 80 percent for the new government and its reform program gave us a clear mandate to clean up the country. This mandate cut across all levels of society and all political parties, and we were determined not to let this rare opportunity go to waste. And while Georgia today is far from flawless, few would deny that it is in an infinitely better place than Georgia in 2003. Paradoxically, it was the crisis that helped us do it. Without the crisis, we would never have been able to turn things around in Georgia. When I look back now, I see the crisis as a blessing in disguise, despite all the hardship that it brought about.

The reforms we implemented to fight corruption in Georgia produced fast results. In a 2003 survey conducted by Transparency International, more than two-thirds of the respondents (67 percent) had said they expected the level of corruption to increase, or stay at the same level, within the next three years. Only one year later, that figure was down to 11 percent. The vast majority of the population had obviously regained trust in the government's ability to return the country to a state of compliance and accountability. In 2007, independent observers recognized that the 
post-revolution government had "done better than any [of its] predecessors at battling corruption" (NYT 2007). ${ }^{1}$

While many of the changes the government made were specific to the situation in Georgia at the time, our fight against corruption rested on three pillars that I consider relevant for any country that is serious about cleaning up its act: the right incentives for government employees, simplification of rules and regulations, and the enforcement of the rules without exemptions. Additionally, I have also come to believe and will demonstrate that regulatory restraint is the best long-term precaution against the resurgence of corruption. By regulatory restraint I mean a degree of regulation that maximizes growth and reflects the capacity of a government to enforce the rules it makes. This degree varies with a given country's economic performance and administrative capability.

\subsection{InCEntives: Carrots ANd STICKS}

Before 2003, the salaries for government officials were so ridiculously low that nobody expected them to work without bribes. ${ }^{2}$ To end the rule of bribery, the new government took a three-step approach.

Step one was to replace most high-ranking officials with a cohort of young, inexperienced, but highly motivated and hard-working people with no track record of corruption. If in doubt, we picked the candidate with a clean record over the tenured professional who might have been entangled in the corrupt practices that we were trying to put an end to. The majority of pre-revolution officials had spent their lives working for the Soviet government. This generation of politicians and administrators was not only accustomed to corrupt practices, their entire political value system was based on the belief that stealing from the government residing in far-away Moscow was a good thing. Unfortunately, this mentality did not change when the Soviet Union unraveled. So the post-revolution government really had no choice but to let the old guard go and run with a new generation of highly motivated, inexperienced people (Fig. 2.1).

Admittedly, this was not a perfect solution. A lot of relevant experience was lost, and not all new hires were not up to their jobs, but this was the price we had to pay if we wanted to start with a relatively clean slate. Of course, there was no guarantee that the newcomers would always play by the rules, but there was a much better chance that they would than for experienced corrupt officials to come clean. By and large, our plan worked out. 


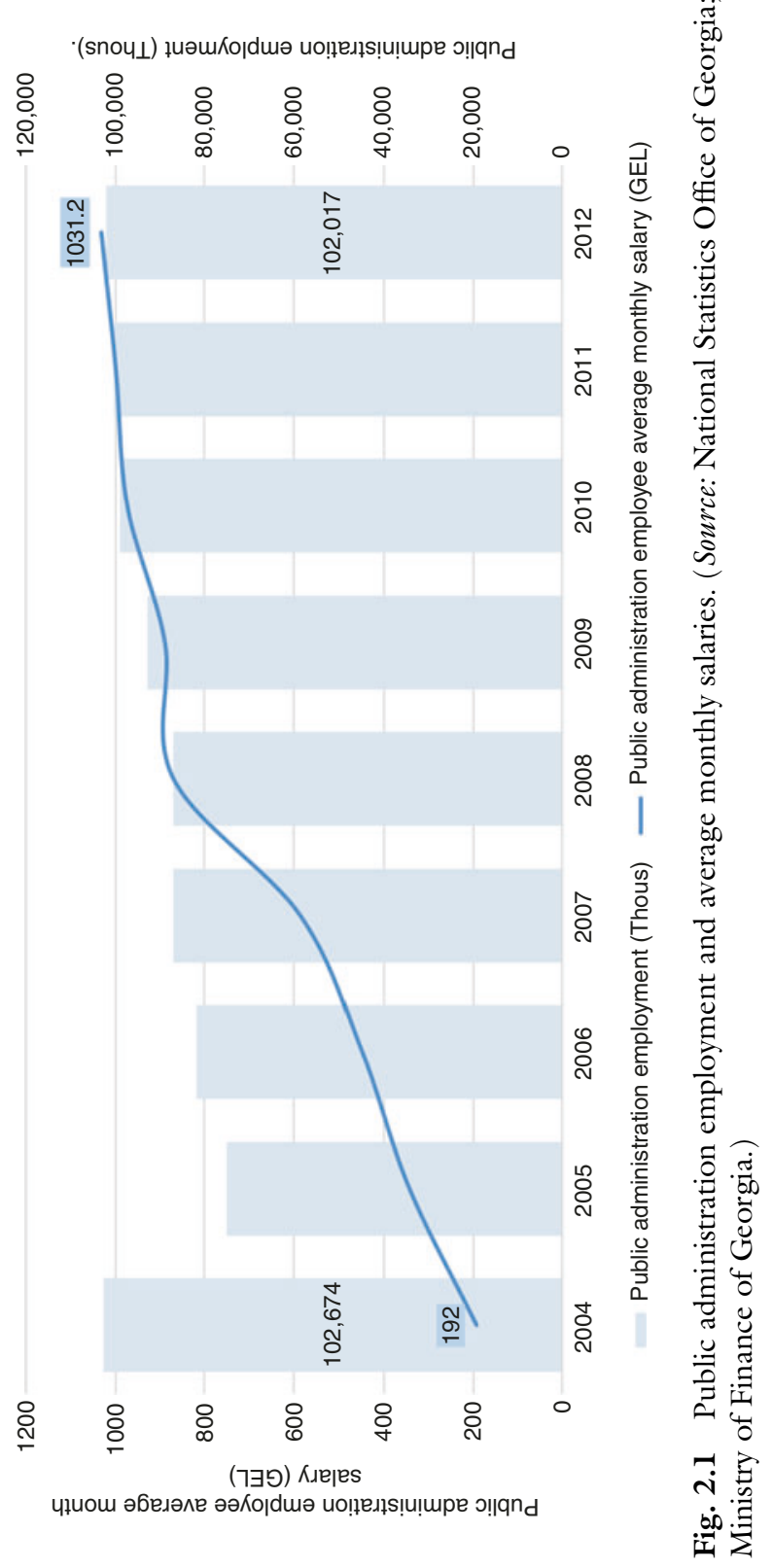


Step two was to increase salaries to make sure public servants would not have to revert to corrupt practices to feed their families. A minister's monthly salary increased from about USD 75 in 2003 to USD 1200 in 2004 , and it increased further in later years. In some cases, average salaries for working-level administrators and members of the traffic police force increased by a factor of ten, from about USD 20 to USD 200. These increases were financed by a significant increase in tax revenues, which I will discuss in the next chapter, and by the eradication of corruption itself. Government officials would not get rich under the new regime, but nobody would have to take bribes to feed their family any longer. In effect, corrupt officials lost the moral high ground. This was an important step on the way to a law-abiding society.

Step three was to infuse public service with a spirit of meritocracy. We introduced a bonus system that rewarded both institutional compliance and personal performance. At the same time, we made it abundantly clear that violators would be punished swiftly and severely. In other words, we promised carrots to those who were willing to build a better Georgia, and we made sure we had the sticks we needed to crack down on corruption.

\subsection{Simplification: The Devil Is in the Details, Unless the Details Are Simple}

Before 2004, the tax system was so complicated and the total tax burden was so high, especially considering the very low level of economic development of the country, that it was widely accepted that no company could pay all of the taxes levied on it and stay in business. A company's tax burden depended on who the tax collector was, what kind of bribe the company offered, and how fierce the competition was in a given industry or region. Bribing the tax collector was the only way to stay in business. With the introduction of the new tax code, the number of taxes was reduced from 21 to 6; see Chap. 5, Reforming Taxes and Customs, for details. All individual tax rates were reduced, and all the remaining taxes were replaced with a flat tax rate system. At the same time, the authorities made it very clear that non-compliance would result in harsh penalties. Specifically, we abolished all exceptions and "special rules" that had previously been granted to members of government, their families, or others who were close to the government in one way or another. 
But we didn't stop at reducing the number of different taxes, rates, and fees. Over the course of the next few years, we also revised the wording of ambiguous regulations. For example, there used to be different customs duties for sports shoes (12 percent) and sneakers $(0$ percent). Similarly, the duty for frozen meat with bones was 12 percent, while there was no customs duty for boneless frozen meat. As a result, Georgia officially never imported any sports shoes or any frozen meat with bones. All imported sports shoes were declared sneakers, and all imported frozen meat, miraculously, turned out to be boneless. To play it safe, importers would routinely bribe customs officers to make sure a given batch of goods was cleared as declared without scrutiny. The regulations were such that both businesses and officials had an incentive to engage in corrupt and illegal practices. The introduction of the new tax code closed most of these loopholes. As a rule of thumb, we tried to make all regulation as clear and precise as possible, and we made sure that all affected parties, public and private, were aware of the applicable laws and rules. To make it even easier for people to contribute to Georgia's growth, we also slashed licenses and permits by nearly 90 percent. We reduced the number of licenses from more than 300 to 41 , and the number of permits from over 600 to 53 .

\subsection{Regulatory Restraint: Less Is More}

At first sight, reducing the number of laws and limiting the role of government may appear counterintuitive as measures in the fight against corruption. But if we look a little closer at human nature, and at the mindset of most bureaucrats in particular, deregulation actually makes a lot of sense as a counter-corruption strategy. Give a government official a desk and a pen, and he will find something to regulate. Occasionally, officials may think that regulation is actually necessary. But more often than not, they will simply come up with new rules to boost their ego, prove that their job is important, or create new opportunities to elicit bribes. This may sound pessimistic, but I have seen it happen in Georgia countless times before 2004, and it is happening in any number of other countries even as you read this. Of course, such self-serving regulation is always marketed to the public as an advancement of the greater good.

Objectively speaking, depending on a country's economic and civic development, different sets of rules and regulations are called for. But in every case, there are two types of rules. On the one hand, there are basic and 
straightforward rules that are necessary to protect human rights, uphold national security, maintain public safety, safeguard the health of the population, and create a level economic playing field. On the other hand, there is the bulk of byzantine rules that primarily promote corruption and inhibit growth. Adjustments are called for at every stage of a country's development, but the main objective of any government should be to keep nonessential regulation to a minimum. More regulation creates more opportunity for corruption and more obstacles for growth. The more hoops a private company has to jump through to do business, the less likely it is to invest in further growth and create new jobs. Internationally, a moderate regulatory footprint has become a source of strategic advantage among countries competing for foreign investment.

More generally, the size of the government is one of the principal influencing factors of any country's growth. While an outsized government usually slows down economic development, a lean government can speed it up. The size of the government can be measured in two dimensions: financial and regulatory. The government's fiscal footprint is mainly determined by its budget as a percentage of GDP; I will examine this aspect in detail in the next chapter. The government's regulatory heft is less easily quantified, but the number and the level of detail of laws and regulations can serve as proxies. The less developed and the more corrupt a given country is, the fewer rules it should have to make sure it can enforce those rules that are essential to uphold order and promote economic growth. Before 2004, Georgia was clearly on the more unfortunate end of this scale. The country was on the brink of bankruptcy, it was highly corrupt, and it had no culture of following rules. Yet there was an over-abundance of rules and regulations. Most of these were the legacy of Soviet rule or had been introduced around the turn of the millennium, officially to comply with international standards. In theory, this process should have made Georgia a more competitive player in the community of nations. But in reality, almost all of the new rules gave rise to corruption and facilitated personal gain by the ruling elite.

For example, traffic codes in many European countries prescribe that all cars be equipped with a special fire extinguisher. As a rule, it makes perfect sense, and it has doubtlessly saved many lives in developed countries. It was introduced in Georgia in the mid-1990s, but with a twist. Prior to the introduction of the requirement, a high-ranking police official had imported a cheap variety of these special fire extinguishers in bulk. And as soon as the rule became effective, all traffic police officers were instructed to stop vehicles, fine the drivers for not having a fire extinguisher, and tell them 
where they would be able to buy one. While some drivers actually bought fire extinguishers, most of them just got used to bribing police officers whenever they were caught without one. To make things worse, the equipment was often faulty, but nobody cared once the sale was made or the bribe was paid. After five months, all fire extinguishers had been sold, and from one day to the next, officers stopped harassing drivers about them, as if the risk of fire had suddenly evaporated. Fighting corruption turned out to be much harder than fighting fire.

Another example is the introduction of general inspections for cars in the 1990s. Car owners had to have their vehicle inspected and obtain a document certifying its road worthiness, irrespective of the age of the vehicle. If anything was wrong with the car, the owner was officially obliged to have it repaired. When drivers were stopped by traffic police, they were to show the certificate upon request. The trouble was that the country was so poor that few people could afford the inspection fee, let alone the cost of repairs. At the time, most of the cars on Georgia's roads dated back to the time when the country was still part of the Soviet Union, and almost all of them needed some degree of maintenance. So what happened is that drivers got used to bribing technical inspectors to obtain the certificate, or to bribing traffic police officers if they were stopped without the proper papers. Again, the cause was noble, much as it had been in the case of the fire extinguishers: to increase everyone's safety on Georgia's roads. But it benefited neither drivers nor pedestrians. The only people who benefited were providers of inspection services, usually set up as private companies owned by high-ranking traffic police officials, and traffic patrolmen. The regulation was abolished in 2004. Again, nothing changed, except a decline in bribes paid to the police.

These are just two out of hundreds of similar cases ${ }^{3}$ in which regulation was introduced to promote public safety, or some other noble cause, but ended up filling the coffers of corrupt officials, even if this had not been the original intention. Often, such rules were actually triggered by requests from more developed countries in exchange for financial aid. While these previous examples refer to individuals, companies were often subject to similarly questionable rules. For instance, every company would have to endure at least half a dozen inspections annually - by different agencies acting on behalf of the Ministry of Finance, the Ministry of Economy, the Ministry of Agriculture, the Ministry of State Security, and, in some cases, by the prosecutor's office. The only purpose these inspections served was to elicit bribes from the private sector. 
Many developing countries today face similar challenges. Foreign governments and international financial institutions press for the introduction of ever more complex rules and regulations, be it to increase their influence in the developing world, or out of sheer ignorance about potential side effects. Sometimes, the justification for new regulation is as trivial as having something to show in return for financial aid. But often, the only effect these new rules have is to engender corruption at the expense of struggling businesses and citizens.

The lesson Georgia learned the hard way is that you cannot impose advanced regulations on a developing country in one fell swoop. In response, the government after 2004 has followed a simple set of guidelines when it came to regulation:

- The country is poor, and the government cannot afford to employ thousands of inspectors to oversee and enforce endless rules and regulations.

- In the past, the government itself and its agencies have been the most corrupt institutions, and at least some officials will likely succumb to corruption again.

- In practice, most rules and regulations are not followed anyway. They do not contribute to the well-being of the population. All they do is cause corruption.

- So let us get rid of all non-essential regulations and simplify the remaining ones to minimize the potential for frustration, confusion, and corruption.

- As the country develops and the economy grows, let us introduce new regulation as it is needed and to the extent that we are able to enforce it.

Following this line of reasoning, Georgia's regulatory framework was reduced to the immediate essentials: fighting corruption, protecting public safety, and collecting taxes. Step by step, we introduced new regulation as it became necessary, and only if we could realistically hope to enforce it. For example, wearing seatbelts in cars became obligatory in Georgia only in 2010. We had considered introducing this rule as early as 2005 , but decided against it for two reasons: firstly, because there was no track record of playing by the rules at the time. We would only have created a new source of bribery for traffic police officers. Secondly, and perhaps even more importantly, because we had no way of enforcing such a rule at the time. In 2004, we had laid off the entire traffic police force. In 2005, we 
were in the process of rebuilding law enforcement from the ground up. And every time you introduce a rule nobody follows, you lose credibility and weaken your stance. But five years later, when people had gradually grown used to paying taxes and respecting the law, the time had come. Now Georgians were ready to accept that regulation was enforced to protect their safety, rather than to elicit illegal revenue streams for government officials. And, finally, we had the kind of police force we could trust to uphold the rules for the sake of public safety, rather than to exploit them for their personal benefit. Almost all drivers immediately started wearing seatbelts when the requirement was finally signed into law in 2010 .

As countries mature, governments contemplating the introduction of new regulation should subject prospective new laws and rules to two tests: Do they help maximize growth? And can they be enforced effectively?

\subsubsection{Growth Maximization}

At any given time, a country's regulatory footprint should reflect the stage of its development. This will help promote sustainable long-term growth. Many countries today are overregulated, and in most of these countries a decrease in the regulatory burden will trigger new growth. Think of this interrelation as the regulatory equivalent of the Laffer curve that describes the interdependence of taxation and governmental revenue. An entirely unregulated country will veer toward chaos and, eventually, collapse. ${ }^{4}$ There will be no growth whatsoever. A fully regulated country, however, will stagnate, like the Soviet Union did. Sooner or later, the economy will break down unless the government allows for some measure of political change and free enterprise, as the Chinese regime currently does. For every country, there is a point on this regulatory curve that maximizes growth. If there is too little regulation, the country will not be able to realize its full economic potential. If there is too much regulation, this will slow down the economy. While its shape and maximum may vary with political and economic parameters, I believe it is instructive as a concept to help governments practice regulatory restraint (Figs. 2.2 and 2.3).

\subsubsection{Enforceability}

Any regulation that cannot effectively be enforced will result in corruption, or at least in a disruption of political stability and economic growth. Ineffective enforcement will also result in unfair advantages for those who 


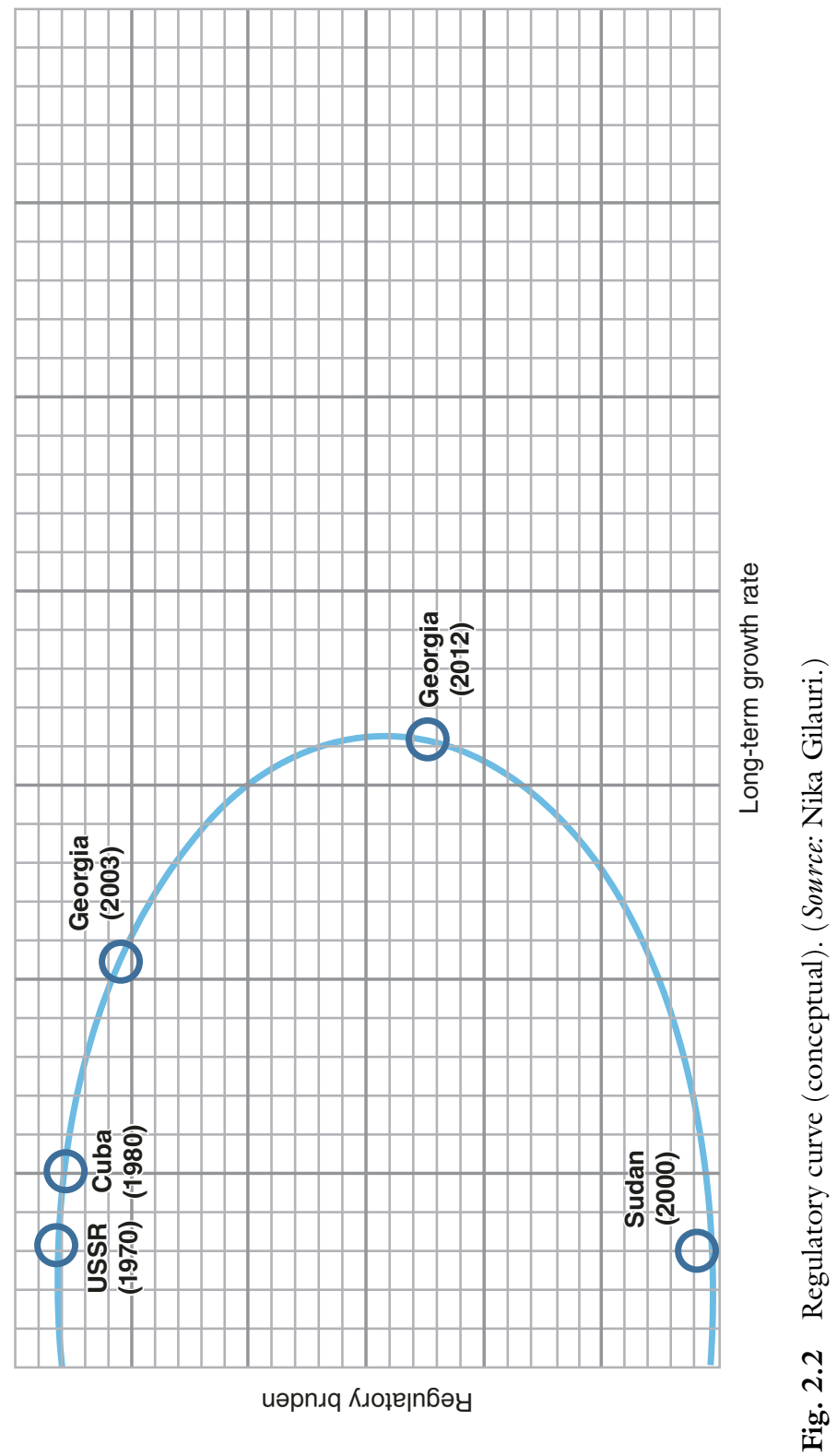




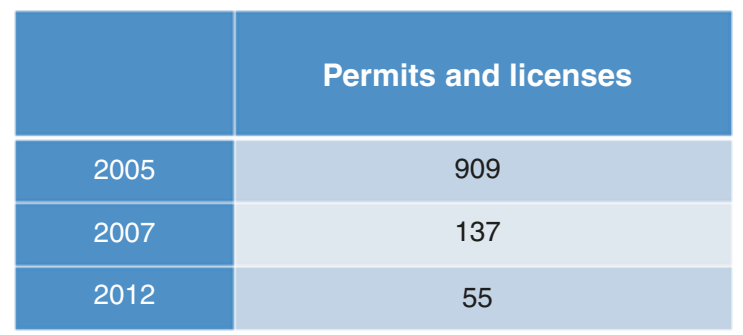

Fig. 2.3 Permits and licenses, 2005-2012. (Source: World Bank - "Fighting corruption in public services: chronicling Georgia's reforms.”)

elude the rules and disadvantages for those who comply. What is more, a government that introduces rules that it cannot enforce loses credibility. So new rules should only be introduced if the legal system, the government's human resources, and funding enable their enforcement. In the European Union, this is usually not a problem. There is sufficient funding and human capital in the member countries to enforce almost any regulation. This may sound like a good thing but it really isn't since many rules that the European Union creates do not pass the growth maximization test. In contrast, Georgia in 2004 was so underdeveloped, yet so overregulated, that the course of radical deregulation we chose passed both tests. At the time, getting rid of the vast majority of licenses and permits was the right thing to do and quickly brought about economic growth.

In combination, these two criteria - growth maximization and enforceability - will help governments practice regulatory restraint, i.e., introduce new regulation only inasmuch as it promotes stability and prosperity, and if it can be enforced.

\subsection{Enforcement: Checks and Balances}

Making rules is easy. Making sure people play by the rules is hard. To help the new cohort of public servants stay clean, we set up a strict system of supervision and enforcement. For example, we created a special compliance department in the traffic police force, inspired in equal parts by the concept of mystery shopping ${ }^{5}$ and by the zero-tolerance policy pioneered by Rudolph Giuliani. ${ }^{6}$ Equipped with hidden cameras, plainclothes agents 
would intentionally break the law under the eyes of a traffic police officer. They had instructions to offer a bribe if they were stopped. If a given law enforcement officer failed to stop the perpetrator, he was fired. If the officer stopped the agent, but accepted the bribe, he went to prison. If he refused the bribe, he was recommended for promotion or given a bonus.

We took a similar approach to increase compliance among customs officers. Protected by special regulations, compliance inspectors set up shell companies to import goods from neighboring countries. During the customs clearing procedure, the compliance inspector would offer a bribe to the customs officer in charge. Those who accepted the bribe went to prison, those who declined the bribe went free, and those who called for backup to arrest the putative fraudster were promoted.

Additionally, we set up a system of bonuses to reward both those who resisted corruption and those who actively fought it. For lower and middle-level government employees, the rewards were focused on getting them to refuse bribes. For more senior officials, the focus was on new and effective ideas for checks and balances, such as the mystery shopping approach or the introduction of electronic tracking and tracing technology for specific goods such as alcohol and tobacco; see Chap. 5, Reforming Taxes and Customs, for details. Some of the bonuses were as high as three to six times a given official's monthly salary.

Sometimes, however, you have to get even more creative. Take the energy sector. In 2003, Georgia's energy sector was riddled with corruption, but it was almost impossible to convict the culprits. Managers of energy distribution companies simply wrote off theft of energy through illegal lines, or embezzlement of funds, as "commercial losses." To make things worse, energy sector managers were in the habit of sharing their black market gains with government officials to buy their silence. To put an end to this and make sure the energy provided was actually paid for, we declared the collection rate ${ }^{7}$ the sector's sole performance indicator. Additionally, we broke the country's biggest distribution company, UDC, down into regional clusters. The grid was split between these clusters in a way that made it very difficult to cheat about the amount of energy received by each cluster. We put a former UDC middle manager in charge of each of the clusters. We reviewed regional collection rates on a monthly basis, and every month, the ten top-performing clusters received a sizeable bonus. We deliberately made the collection rate, i.e., the energy that was paid for as a percentage of the energy that was actually consumed by a given cluster, the only performance metric 
for these managers to make the bonus system as simple and as transparent as possible. In contrast, the management of the worst-performing clusters was laid off - every month. When we were done, Georgia's energy sector was pretty much corruption-free. The collection rate (including commercial losses) went from 30 percent in 2004 to 91 percent in 2007 , one of the fastest improvements of its kind globally.

A similar incentive system was implemented as part of our reform of the higher education sector, another part of the administration that was riddled with corruption. Previously, schools had received funding directly from the Ministry of Education. Schools would routinely bribe government officials to receive extra funds. The principal idea of our reform was to let the money follow students rather than schools. As a first step, we started distributing education vouchers to individuals that replaced direct subsidies to schools. Students and their parents could now freely choose a school - public as well as private, and without any geographical limitation. Schools could convert the vouchers they received from students to cash. This created healthy competition between schools and led to a surge in private school development. As a second step, we extended the concept of motivational performance rewards from institutions to individuals. But instead of introducing a complex scoring system for teachers, principals, and facilities at different types of schools, every high school was simply assessed based on the achievements of its students in university entrance exams, or based on schools' final exams in later years. We chose this metric both because of its simplicity and because it reflected the main interest of students and their parents. The results were widely advertised, thereby intensifying competition between schools for students and their vouchers. For details, see Chap. 10, Education - School Financing and University Reform.

Across the board, we put an end to the exceptions and benefits that had previously been granted to members of the elite. Before, students were only admitted to sought-after university programs if a "protector" made a phone call to university officials, or if they paid a bribe. Students without connections were left out, even if they were smart and worked hard. We were determined not to let this happen again. If there is a rule, it is imperative that it applies to everyone without exception. I firmly believe that this is the only way to establish respect for the rules and make people understand that rules are enforced for their protection, rather than for the 
sake of oppression or as a source of illegal income for the chosen few. How can anyone expect people to respect the law if even the representatives of the state itself don't respect it, or only if and when it suits them?

\subsection{Procurement - Balancing Transparency WITH FLEXIBILITY}

Rules for state procurement are all about finding the golden middle ground. All state procurement is prone to corruption, not only in developing countries. Hence the most important objective for regulation governing procurement is to make the process as transparent as possible and minimize the risk of corrupt deals. At the same time, overly strict procurement rules will limit the efficiency of the government and might make it impossible to acquire the best product on the market. For example, if the rules say that the government must always choose the cheapest option, high-end products will automatically be excluded from the process. Also, there should be different rules for different areas of procurement. Professional services, for example, cannot and should not be procured based on prices alone. Think of marketing, consulting, architecture, and other such intellectual property. Assume a country wants to advertise its investment opportunities in a certain industry, or promote itself as a travel destination on international television. Further assume that the cheapest bidder for the advertising campaign is a local TV station covering one city and half a dozen villages. Chances are that their offer, although it has the lowest price tag, is not the best deal. The most important prerequisite of sound procurement is a solid description of the goods and services to be procured. It should neither be too broad, nor should it be too specific in identifying a particular product if there is a possibility of competition.

In Georgia, the best results in procurement were based on three success factors:

1. Electronic auction. The tender and the specifications are put online. Candidates register and bid online. This approach helps the government eradicate ambiguity and rumors. For example, one participant will often tell others that their company already has a pre-arranged deal with the government, and that the others need not even apply. If everything happens online, the process is both transparent and 
anonymous. The conditions are clear, but nobody knows who the other bidders even are.

2. Two-envelope approach. For every tender, each bidder needs to submit two envelops, one containing the technical description and the other the financial proposal. If the technical description does not meet the requirements, the bidder is excluded from the tender and the second envelop is not even opened. Many governments have adopted this approach, and it generally serves them well. As a next step, the government has two choices: either announce that everybody who passes the quality check has the same chance to win the tender, and that the contract will go to the bidder who offers the lowest price. Or announce that every bidder passing the quality check will be assigned a score for the technical description and that a combined technical-financial score will be generated before the final decision is made.

3. Two-round price auction. The government found that companies generally offer better prices in live auctions, where they have a chance to improve their offers, than in sealed envelope auctions. The government decided to combine the merits of both practices and implemented two-round price auctions: Bidders submit sealed envelopes in a first round, then enter a live online auction in which all bidders can improve their prices. Once the technical descriptions are evaluated and finalists are identified, the price envelopes are opened and the prices are disclosed. The bidder with the best price in the envelope is allowed to go last in the online auction. The other bidders follow in ascending order of their initial offers. Every bidder has a three-minute interval to bid, and the best price wins after three rounds of bidding. This approach brought substantial savings in Georgia, and it can easily be adopted by other countries.

\subsection{Trust Regained and Books Rebalanced}

As early as 2007, independent observers acknowledged that the post-revolution government had "done better than any [of its] predecessors at battling corruption, standing up to Moscow and respecting civil liberties." 8 In 2010 and 2011, I traveled widely across former Soviet territories and eastern European countries. Georgia was a big topic and, in fact, considered 
a role model almost everywhere I went. People would ask, if Georgia can end corruption, why can't we? If their traffic police doesn't take bribes, why does ours? If their administration is fast and clean, why isn't ours? Georgian reforms inspired many governments to follow suit. Over the course of the last few years, Georgia has received government delegations from dozens of countries seeking to study and replicate the reforms.

The World Bank itself has published a book-length report ${ }^{9}$ that describes the Georgian reforms and promotes the principles on which they are based on globally (see following text for details).

In 2012, it was safe to say that we had won the fight against corruption. In Transparency International's Corruption Perception Index, Georgia leaped from the bottom of the table (rank 127 out of 133, below Venezuela) in 2003 to rank 51 in 2012, ahead of Italy. ${ }^{10}$ By another measure, Georgia is one of the least corrupt countries in the world. According to the survey-based 2013 Global Corruption Barometer, only 4 percent of respondents in Georgia said they had paid any bribes in the past year to any of the eight services that were part of the report, namely police, judiciary, registry, land, medical, education, tax, and utilities. This puts Georgia in the best bracket, ahead of the United Kingdom, where 5 percent of respondents admit to having paid bribes ${ }^{11}$ (Fig. 2.4).

At the same time, the Organisation for Economic Co-operation and Development (OECD) acknowledged that "Georgia has achieved significant progress in reducing corruption." 12

The World Bank's 2012 publication "Fighting Corruption in Public Services - Chronicling Georgia's Reforms"13 highlights the following success factors:

- Exercise strong political will

- Establish credibility early

- Launch a frontal assault

- Attract new staff

- Limit the role of the state

- Adopt unconventional methods

- Develop a unity of purpose and coordinate closely

- Tailor international experience to local conditions

- Harness technology

- Use communications strategically 


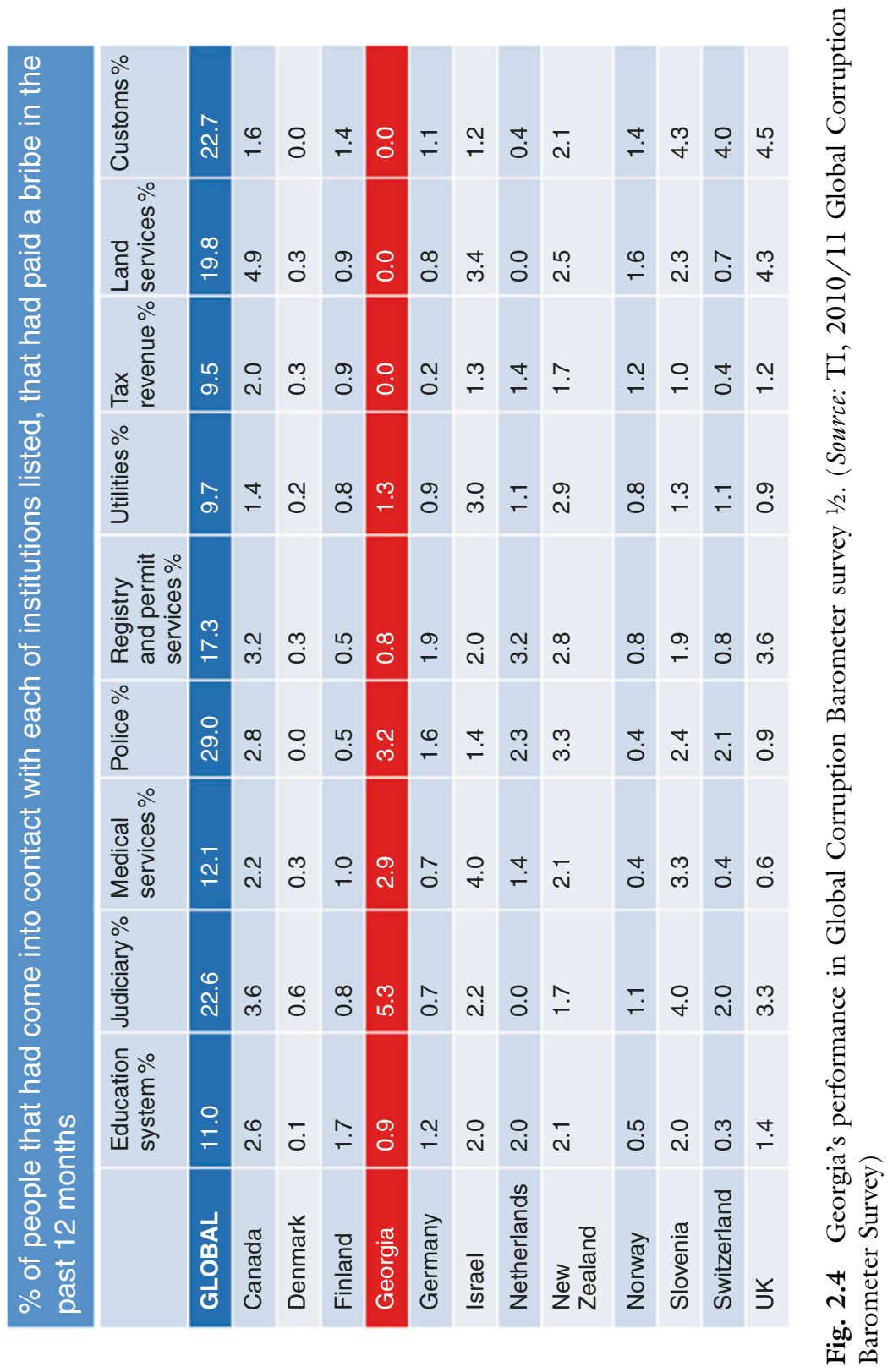




\subsection{Bonus Systems}

Various systems exist to reward civil servants for good performance, e.g., based on key performance indicators (KPIs). Georgia introduced such a system between 2010 and 2012 for the top officials in each ministry, recognizing that their decisions had far-reaching implications for the stability and the prosperity of the country. The KPIs had to be easy to measure. They were negotiated between the relevant minister and the prime minister in front of the rest of the cabinet before the start of each year. For example, foreign direct investment (FDI) and privatization proceeds were the KPIs for the minister of economy. For the tourism department within the Ministry of Economy, the number of tourists served as a KPI. For the minister of energy, the KPIs included net electricity exports and total FDI in the energy sector. In contrast, the minister of healthcare was assessed based on a set of much more diverse, highly specific KPIs, such as the number of newly built hospitals and the decrease in infant mortality. The examples are from 2011 , and they reflect the government's political priorities at the time, namely the focus on FDI as the most important driver of Georgia's economy. For some ministries, such as the Ministry of Foreign Affairs, no straightforward KPI presented itself. How do you measure the performance of the minister of the exterior? By counting the number of embassies established, or by the number of motions tabled at the United Nations in a given year? In such cases, we used an average of the KPIs of other ministries. The prime minster reviewed a minister's performance on a quarterly basis. Based on this review, the minister was paid, or not paid, a bonus and given additional funds to reward those among his staff who contributed the most to the good performance of the ministry. In my experience, KPIbased variable pay is a much better way to reward performance than a plain increase in salaries for government employees. It is less of a burden on the budget, it is less politically controversial, and it ties a civil servant's pay directly to the government's agenda.

A more innovative approach to reward the performance of high-ranking civil servants, prevent the misuse of power, promote democracy, and create a better environment for the private sector can be Country Performance Formula (CPF). It is modeled on the practice of publicly traded companies to compensate management (partially) with share options. Typically, only some of these share options can be cashed by an executive immediately. The bulk of such a package is usually subject to a 
barring clause and can only be cashed in after one, two, or three years. This is to make sure that managers keep the future viability, profitability, and growth of the company in mind. The beauty of the CPF is that it is based on the assessment by an external authority, the stock market, rather than by some internal function or special department.

CPF applies this proven model to the public sector. In my view, 10-year Eurobonds, or comparable debentures, are the best vehicles to play the part of share options for top civil servants:

- The price of Eurobonds is not determined by some department of statistics or the International Monetary Fund, but by financial markets.

- The price is a single figure that reflects all relevant variables, such as the economic development, the political situation, and geopolitical challenges. Also, the price reflects current performance as well as the valuation of future opportunities and risks. For example, the price of the Eurobond will decrease if a country's economic performance deteriorates, or if elections are not free and democratic. It will also go down if unemployment or inflation soars. In contrast, the price will go up if the economic situation, political stability, or international relations improve.

- The price affects public finances and private players alike. If the price goes up, both the state and private enterprises have access to cheaper capital. The whole economy benefits from the lower interest rates that ensue: the state budget, local banks, local companies, and individual borrowers. Also, a higher Eurobond price results in higher-priced local assets, higher prices of local companies, higher income for local entrepreneurs, better visibility of the country on international financial markets, and, hence, more opportunities to attract investors, create jobs, and reduce unemployment.

This is why I believe that the Eurobond is the best basis for the measurement of governmental performance, and that government employees should be rewarded in line with the development of the price of the bond. The formula should be drawn up in such way that a top-performing bond puts civil servants on an even keel with their peers in the private sector in terms of their income.

There is one issue though. Public figures have a tendency to try to hold on to power, sometimes longer than is in the interest of the country, or 
even, in the worst case, against the will of the electorate. To counter this tendency, the CPF should be set up in a way that puts Eurobond options on hold until government employees have completed their full term without charges of fraud or improper conduct. The term should correspond to a given country's electoral cycles, but not exceed ten years. Some critics argue that the price of Eurobonds may vary with factors that are out of the government's control, such as the global economic situations or geopolitical landslides. This is why the bonus should be based not on the face value of a country's Eurobond itself, but on its performance relative to some reference paper, such as U.S. treasury bonds, or relative to the average of a set of similar countries, or on Credit Default Swaps.

If such a scheme is implemented, the objective of the government will change automatically. The main concern of most members of government is to be re-elected as a party, as a president, or as a cabinet. And governments are often prepared to sacrifice the long-term economic prosperity of the country to short-term populism that will get them re-elected. With a CPF in place, governments will shift their focus to long-term sustainability. If their own income depends on the performance of their country as valued by international financial markets, top civil servants will think twice before committing to higher pensions, or higher welfare payments, without securing the necessary budgetary means.

That said, power itself is still a powerful potion. Some people will try to stay in power regardless of the cost. The CPF will not change the minds of such power junkies. All I am arguing is that a bonus that is based on a country's performance creates an incentive for the average civil servant to balance short-term benefits with long-term prospects. Additionally, the Western world may want to adopt a "Global Magnitsky List" for all corrupt officials; Sergei Magnitsky was a Russian lawyer who uncovered corrupt schemes of the Russian government and was jailed by Russian authorities. He died in prison under suspicious circumstances. Later, the United States Congress adopted a bill according to which all members of the authorities who were involved in the case were deprived of U.S. visas, and their accounts and assets in the United States were frozen. ${ }^{14}$ Combining a CPF with such a black list would create a carrot and stick scheme for high-ranking government officials and may help transform the state of developing world within a decade or two.

Ideally, a CPF should be introduced by a government that itself does not benefit from it. In other words, the next government should be the 
first beneficiary of the formula. This will help resolve concerns about self-enrichment and make it much easier to justify such a scheme in the public eye. ${ }^{15}$

\subsection{OutLOOK}

While the impact of deregulation in Georgia was almost universally beneficial, it can also backfire on occasion. For example, there was an institute in Georgia that oversaw the certification of sailors. The institute trained aspiring sailors and awarded them a certificate upon successful completion of the course. These certificates are required for sailors seeking jobs with international shipping companies. But much like the technical inspection service for cars and similar organizations in Georgia at the time, the seaman's institute gave out certificates in exchange for bribes without actually providing any training. In effect, even certified Georgian sailors frequently found themselves insufficiently prepared to work abroad. In response, the government closed down the institute and allowed private companies to offer training and certification for sailors. But it turned out that EU regulation required the certifying body to be a licensed government institute, rather than a private company. As a result, hundreds of Georgian sailors found themselves barred from working on ships that entered EU ports and lost their jobs.

But mishaps like this don't change the fact that regulatory restraint generally helps curtail corruption and promote growth. Fewer and less complex rules provide less opportunity for corrupt officials to elicit bribes or to make life difficult for companies and citizens in other ways. At the same time, restrained regulation also increases the prospects of compliance by the general public. If playing by the rules is comparatively cheap and easy, why would people bother to cheat?

Of course, deregulation must not compromise high-ranking constitutional objectives such as national security, public safety, health, free enterprise, freedom of opinion, and equal opportunity to participate in the pursuit of prosperity. At every stage of a country's economic development and institutional maturity, the government needs to re-assess the adequacy of its regulation and its capability for effective enforcement of the rules. New rules will become necessary, and old rules will become obsolete.

In what follows, I will turn to reforms in specific fields such as taxes, customs, energy, welfare, healthcare, and education. While these areas were faced with different challenges, the fight against corruption permeates almost every aspect of post-revolution reform in Georgia, especially as 
regards the size of government. Most countries today are overregulated, and the regulatory burden impairs their economic development. But big governments not only slow down growth, they are also more susceptible to corruption. What is true for regulation is also true for government as a whole: Less is more.

\section{Notes}

1. Roses and Reality in Georgia, New York Times, November 10, 2007, http://www.nytimes.com/2007/11/10/opinion/10sat3.html (retrieved in 2015). (New York Times 2007).

2. When I started to work for the Ministry of Energy in 2004, my monthly salary was GEL 120, at about two Georgian laris to the dollar, i.e., about USD 60. A head of a department made about GEL 60-80, or USD 30-40, per month. The average salary at the time was about GEL 40, or USD 20.

3. More examples are available if needed, related to International Financial Institutions and/or EU requests.

4. One example of this is Sudan. According to the BBC, South Sudan (split off from Sudan in 2011) in particular has what many describe as a "war economy." See http://www.bbc.com/news/world-africa-34075573 (retrieved in August 2015).

5. Mystery shopping as a concept originates in retail. Manufacturers of consumer goods send anonymous representatives to the stores where the goods are sold. The purpose of these visits is to check whether the goods are stocked, displayed, and priced as agreed between the manufacturer and the retailer. Some companies, such as consumer banks or telecommunications providers, also send mystery shoppers to their own branches to check on sales staff, making sure they follow corporate protocol and provide adequate advice to customers. For details, see Willie Osterweil, The Secret Shopper, The New Enquiry, June 4, 2012. (Osterweil 2012).

6. See Norimitsu Onishi, Be Polite or Else, Giuliani Warns in Announcing Civility Campaign, New York Times, February 26, 1998 (Onishi 1998).

7. Energy paid for as a percentage of the total energy supplied (not billed).

8. Roses and Reality in Georgia, New York Times, November 10, 2007, http://www.nytimes.com/2007/11/10/opinion/10sat3.html (retrieved in 2015) (New York Times 2007).

9. http://documents.worldbank.org/curated/en/2012/01/15647088/ fighting-corruption-public-services-chronicling-georgias-reforms (retrieved in August 2015).

10. http://www.transparency.org/research/cpi/overview (retrieved in August 2015). 
11. http://www.transparency.org/gcb2013/results (retrieved in August 2015).

12. http://www.oecd.org/corruption/acn/GEORGIAThirdRound MonitoringReportENG.pdf (retrieved in August 2015).

13. http://documents.worldbank.org/curated/en/2012/01/15647088/ fighting-corruption-public-services-chronicling-georgias-reforms (retrieved in August 2015).

14. Max Seddon and Neil Buckley, Russia: Magnitsky's bitter legacy, Financial Times, June 12, 2016 (Seddon and Buckley 2016).

15. A system that is similar to CPF is in place in Singapore. It is, however, not based on the prices of state bonds, but on the average salaries of privatesector CEOs at companies operating in the industry that falls in a given minister's or civil servant's remit. This approach is based on idea that the private sector is the main driver of the economy and that the public sector should do anything to create a better environment for the private sector.

Open Access This chapter is distributed under the terms of the Creative Commons Attribution 4.0 International License (http://creativecommons.org/licenses/by/4.0/), which permits use, duplication, adaptation, distribution and reproduction in any medium or format, as long as you give appropriate credit to the original author(s) and the source, provide a link to the Creative Commons license and indicate if changes were made.

The images or other third party material in this chapter are included in the work's Creative Commons license, unless indicated otherwise in the credit line; if such material is not included in the work's Creative Commons license and the respective action is not permitted by statutory regulation, users will need to obtain permission from the license holder to duplicate, adapt or reproduce the material.

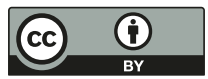

